\title{
Pengaruh Work-Family Conflict, Job Stress dan Emotional Exhaustion Terhadap Job Performance Karyawati Puskesmas Ayah I
}

\author{
Surur Khomsa ${ }^{1}$, Indah Rohyani ${ }^{2}$ \\ 1,2 Universitas Putra Bangsa \\ Email: sururkhomsa911@gmail.com ${ }^{1}$
}

\section{ARTICLE INFO}

Article History:

Received: June $10^{\text {th }} 2021$

Accepted: June $15^{\text {th }} 2021$

Published: June $16^{\text {th }} 2021$

Keywords:

Work-Family Conflict, Job

Stress, Emotional

Exhaustion, Job

Performance

\begin{abstract}
Tujuan penelitian ini adalah untuk mengetahui pengaruh workfamily conflict, job stress, dan emotional exhaustion terhadap job performance karyawati di Puskesmas Ayah I, baik secara parsial maupun secara simultan. Penelitian ini merupakan penelitian survei dengan responden sebanyak 30 orang responden yang bekerja sebagai karyawati di Puskesmas Ayah I. Pengumpulan datanya menggunakan kuesioner yang telah diuji validitas dan reliabilitasnya, sedangkan analisis datanya menggunakan analisis regresi linear ganda (uji $\mathrm{t}$ dan uji $\mathrm{F}$ ), yang sebelumnya telah dilakukan uji prasyarat analisis meliputi uji normalitas, multikolinearitas, dan heteroskedastisitas. Setelah dilakukan analisis data, diperoleh hasil dan kesimpulan sebagai berikut: (1) Work-family conflict berpengaruh negatif dan signifikan terhadap job performance karyawati di Puskesmas Ayah I. (2) Job stress berpengaruh negatif dan signifikan terhadap job performance karyawati di Puskesmas Ayah I. (3) Emotional exhaustion berpengaruh negatif dan signifikan terhadap job performance karyawati di Puskesmas Ayah I (4) Work-family conflict, job stress, dan emotional exhaustion secara simultan berpengaruh terhadap job performance karyawati di Puskesmas Ayah I.
\end{abstract}

\section{Pendahuluan}

Puskesmas adalah fasilitas pelayanan kesehatan yang menyelenggarakan upaya kesehatan masyarakatdan upaya kesehatan perseorangan tingkat pertama, dengan lebih mengutamakan upaya promotif dan preventif, untuk mencapai derajat kesehatan masyarakat yang setinggi-tingginya di wilayah kerjanya (Peraturan Menteri Kesehatan Republik Indonesia nomor 75 Tahun 2014).

Puskesmas merupakan sebuah tempat yang sangat mengutamakan dan mengedepankan pelayanan masyarakat. Pelayanan yang baik ini sangat ditentukan oleh para pegawai, karyawati, dan perawat yang bekerja puskesmas. Karena hal tersebut, seseorang yang bekerja di puskesmas, baik pegawai, karyawati dan perawat harus dapat melayani pasien dengan baik dan tidak mengecewakan.Selain itu, pelayanan yang cepat dan tanggap juga 
sangat diperlukan puskesmas untuk dapat menangani pasien yang datang untuk melakukan pelayanan medis.

Upaya puskesmas dalam meningkatkan pelayanan yang lebih bermutu tidak terlepas dari peran sumber daya manusia yang ada di dalamnya.Sumber daya manusia yang ada harus dikelola dengan baik.Pengelolaan sumber daya manusia merupakan aspek yang sangat penting bagi keberlangsungan puskesmas. Pengelolaan sumber daya manusia perlu diarahkan pada suatu model yang dapat menarik seluruh potensi sumber daya manusia tersebut bagi kepentingan puskesmas atau dengan kata lain pengelolaan sumber daya manusia harus diarahkan dengan upaya untuk menggali potensi sumber daya manusia agar dapat memberikan kontribusi yang maksimal bagi puskesmas.

Sebagaimana dikemukakan oleh Mangkunegara (2007) bahwa istilah kinerja berasal dari kata job performance atau actual performance (prestasi kerja atau prestasi sesungguhnya yang dicapai oleh seseorang) yaitu hasil kerja secara kualitas dan kuantitas yang dicapai oleh seorang karyawan dalam melaksanakan tugasnya sesuai dengan tanggungjawab yang diberikan kepadanya.

Berdasarkan fenomena yang terjadi di lapangan bahwa karyawati Puskesmas Ayah I mempunyai tuntutan untuk bekerja secara professional, harus tetap setia melayani pasien dengan sabar dan cepat tanggap terhadap segala masalah yang terjadi pada pasien yang datang merupakan tugas yang harus dijalankan oleh karyawati tersebut. Seperti, menangani pasien yang akan melakukan persalinan harus membutuhkan penanganan yang cepat, tepat dan cekatan, walaupun tanpa ada seorang dokter kandungan, karena Dokter tidak selalu ada di ruang persalinan. Professional atau tidaknya seorang karyawati, diukur dari kinerja karyawati dalam bekerja setiap harinya.

Work-Family Conflict adalah salah satu bentuk interrole conflict tekanan atau ketidakseimbangan peran antara peran di pekerjaan dengan peran di dalam keluarga (Greenhaus \& Beutell, 1995). Work-Family Conflict dapat didefinisikan sebagai bentuk konflik peran di mana tuntutan peran dari pekerjaan dan keluarga secara mutual tidak dapat disejajarkan dalam beberapa hal. Misalnya pada saat seseorang berusaha memenuhi tuntutan perannya dalam pekerjaan dan usaha tersebut dipengaruhi oleh kemampuan orang yang bersangkutan untuk memenuhi tuntutan keluarganya atau sebaliknya, dimana pemenuhan tuntutan peran dalam keluarga dipengaruhi oleh kemampuan orang tersebut dalam memenuhi tuntutan pekerjaannya (Frone, 2000).

Hal ini lebih sering terjadi pada wanita yang sudah berumah tangga. Work-Family Conflict yang berhubungan kuat dengan depresi dan kecemasan lebih sering dialami oleh wanita dibandingkan pria. Terlebih, peningkatan jumlah tenaga kerja wanita pada tingkat manajemen dimana mereka menjadi lebih berpengaruh dan memiliki kontrisbusi yang cukup besar terhadap kinerja perusahaan menyebabkan keseimbangan antara kehidupan pekerjaan dan keluarga menjadi suatu tuntutan. Namun bukan tidak mungkin jika masalah ini terjadi pada pria, dimana satu sisi ia bertanggungjawab terhadap kehidupan keluarganya, dan disisi lain ia berusaha memenuhi kewajibannya dalam bekerja.

Berdasarkan fenomena yang terjadi di Puskesmas Ayah l, bahwa beberapa karyawati mengalami work-family conflict, karena harus membuat perubahan rencana untuk keluarga karena kewajiban pekerjaanya di puskesmas Ayah 1. Seperti membagi waktu antara pekerjaan rumah dengan pekerjaan puskesmas dengan baik tanpa merugikan keluarga dan pekerjaan utamanya. Menjalani peran sebagai karyawan dan sebagai ibu rumah tangga mendatangkan banyak persoalan yang dialami oleh para wanita, yang juga sebagai ibu rumah tangga yang bekerja diluar rumah. Tuntutan perangan dan sebagai ibu rumah tangga 
dan sebagai tenaga kerja wanita semakin sulit dimainkan secara seimbang, keduanya saling tarik dan membuat wanita bekerja kesulitan untuk melakukan manajeman peran dan manajeman waktu.

Menurut Beehr dan Newman Dalam Luthan (2011) Job Stress merupakan kondisi yang timbul dari interaksi individu dan pekerjaan mereka yang ditandai oleh perbuatan dalam diri yang memaksa mereka untuk menyimpang dari fungsi normal mereka. Berdasarkan hasil interview dilapangan kenyamanan lingkungan kerja menjadi salah satu penyebab stress kerja terhadap karyawati Puskemas Ayah I, lingkungan yang nyaman tidak akan melelahkan dan membuat karyawati tertekan. Kurangnya dan buruknya interaksi dengan sesama rekan kerja tidak akan dapat menghasilkan kerja sama yang baik dan tidak adanya persaingan yang menghambat dalam melaksanakan tugas pokok dan fungsi Puskemas Ayah I, kurangnya dorongan dari atasan atau atasan yang terlalu ikut campur dengan kegiatan karyawati mengakibatkan karyawati sulit melakukan penyesuaian diri dengan lingkungan fisik maupun sosialakan mengakibatkan ketidakpuasan dalam kerja yang dapat mengakibatkan stress kerja.

Kondisi personal dan organisasional karyawan juga harus diperhatikan, kelebihan beban kerja, ketidakjelasan peran dan konflik menyebabkan karyawan mendapat tekanan saat bekerja sehingga membutuhkan waktu lebih untuk menyelesaikan yang dapat berakibat pada kondisi personal, ketika karyawati tidak dapat membagi waktu kerja dengan keluarga sehingga mengakibatkan stress kerja, tidak hanya karena kondisi organisasional tetapi juga berdampak pada kondisi personal dan keluarga karyawati. Pada akhirnya stress kerja yang berlebihan akan berdampak pada kepuasan karyawati, sehingga mempengaruhi kinerja karyawati yang mengakibatkan tidak maksimalnya dalam menjalankan tugas pokok dan fungsi Puskesmas Ayah I.

Stress kerja atau job stress yang berkepanjangan dapat menyebabkan kelelahan emosi atau emotional exhaustion. Menurut Khoiriyah (2011) Emotional exhaustion adalah kelelahan individu yang berhubungan dengan perasaan pribadi yang ditandai dengan rasa tidak berdaya dan depresi. Kinerja para wanita sering terhambat karena wanita lebih cenderung mengalami emotional exhaustion daripada pria. Hal ini dikarenakan wanita mempunyai peranan ganda yang terkadang mengharuskan untuk memilih salah satu diantara dua peran (gaines \& Jermier, 1983). Wanita mempunyai waktu yang sulit dalam menukarkan antara kepentingan keluarga dengan pekerjaan (Posig \& Kickul, 2004).Tentunya keduanya mempunyai pengaruh terhadap job performance wanita di tempat kerja (Noor, 2003).

\section{Kajian Teori dan Telaah Literatur}

\section{Job Performance}

Menurut Mangkunegara (2010: 9) kinerja karyawan (prestasi kerja) adalah hasil kerja secara kualitas dan kuantitas yang dicapai oleh seseorang karyawan dalam melaksanakan tugasnya sesuai dengan tanggung jawab yang diberikan kepadanya. Indikator kinerja menurut Bernadin dan Russel yang dikutip Gomes Lardoso Faustino (2000: 135) dibatasi pada:
a. Quantity of work
b. Quality of work
c. Job knowledge
d. Creativeness
e. Cooperative
f. Dependability
g. Initiative 


\section{h. Personal qualities}

\section{Work-Family Conflict}

Work-Family Conflict adalah salah satu bentuk interrole conflict tekanan atau ketidakseimbangan peran antara peran di pekerjaan dengan didalam keluarga (Greenhaus \& Beutell, 1995). Menurut Greenhaus \& Beutell (1985) Work family conflict dilihat dari beberapa indikator, yaitu sebagai berikut :
a. Time Based Conflict
b. Strain Based Conflict
c. Behavior Based Conflict

\section{Job Stress}

Stress sebagai suatu tanggapan dalam menyesuaikan diri yang dipengaruhi oleh perbedaan individu dan proses psikologis, sebagai konsekuensi dari tindakan lingkungan, situasi atau peristiwa yang terlalu banyak mengadakan tuntutan psikologis dan fisik seseorang (Luthans, 2000). Menurut Hasibuan (2014:204) menyatakan bahwa adapun model stres kerja yang menjadi indikator stres kerja adalah sebagai berikut:
a. Beban kerja
b. Sikap pemimpin
c. Waktu kerja
d. Konflik
e. Komunikasi
f. Otoritas kerja

\section{Emotional Exhaustion}

Menurut Pines dan Aronson (1989), emotional exhaustion merupakan kelelahan secara fisik, emosional, dan mental yang disebabkan keterlibatan jangka panjang dalam situasi yang penuh dengan tuntutan emosional. Menurut Maslach, Schaufeli, dan Leiter (2001:404) dalam Miranda (2013:136) ada tiga aspek dalam kelelahan emosional yang dapat dijadikan sebagai indikator yaitu:
a. Fisik
b. Emosi
c. Mental

\section{Model Empiris}

Berdasarkan landasan teori yang telah dibahas sebelumnya yang menyakut variabel bebas (independent variable) yaitu variabel yang mempengaruhi atau yang menjadi sebab adalah perubahanya atau timbulnya variabel dependent (terikat). Variabel independent dalam penelitian ini yaitu work-family conflict, job stress, emotional exhaustion dan variabel dependent (terikat) adalah job performance. 


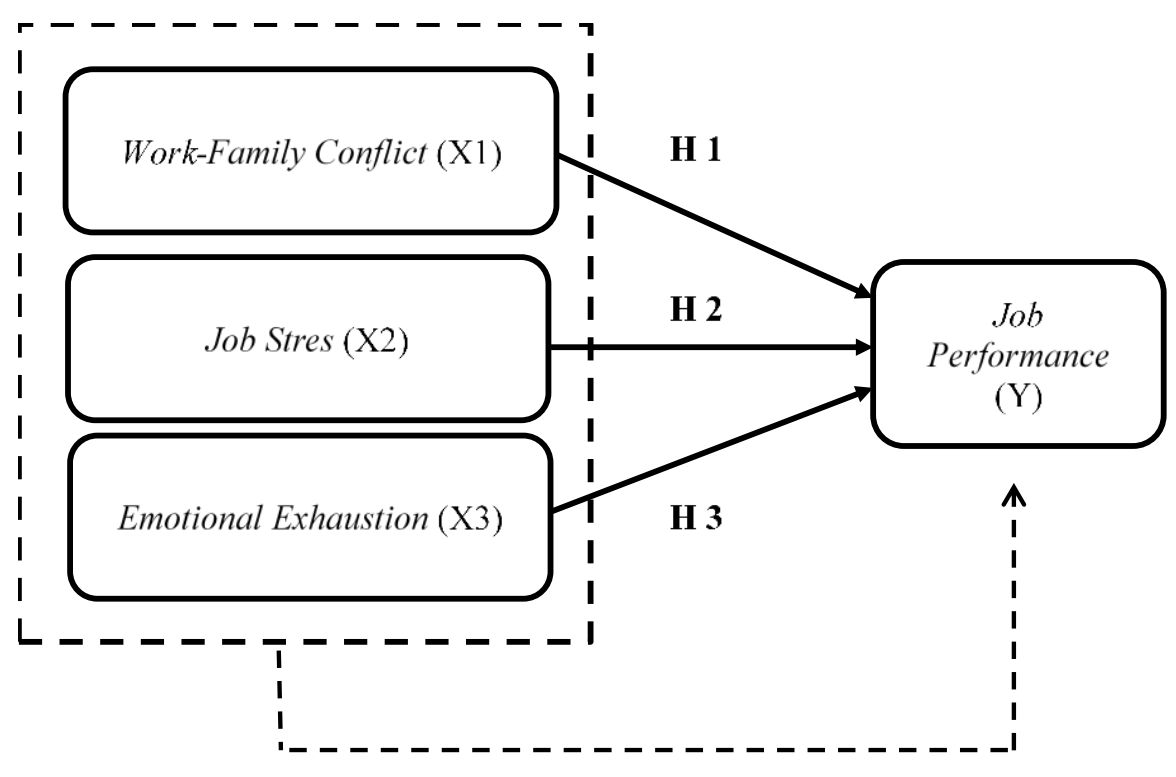

Gambar 1. Model Empiris

\section{Hipotesis}

Berdasarkan model empiris di atas dapat dirumuskan hipotesis penelitian sebagai berikut: $\mathrm{H}^{1}$ : Ada pengaruh work-family conflict terhadap job performance Karyawati Puskesmas Ayah I $\mathrm{H}_{2}$ : Ada pengaruh job stress terhadap job performance Karyawati Puskesmas Ayah I.

$\mathrm{H}_{3}$ : Ada pengaruh emotional exhaustion terhadap job performance Karyawati Puskesmas Ayah I $\mathrm{H}_{4}$ : Ada pengaruh work family conflict, job stress, dan emotional exhaustion secara simultan terhadap job performance Karyawati Puskesmas Ayah I

\section{Metode Penelitian}

Obyek pada penelitian ini adalah job performance sebagai variabel terikat (dependent variabel) dan work-family conflict, job stress dan emotional exhaustion sebagai variabel bebas (independent variabel). Subyek dalam penelitian ini adalah karyawati Puskesmas Ayah I, yang berjumlah 30 orang.

\section{Teknik Pengambilan Sampel}

Teknik pengambilan sampel dalam penelitian ini adalah dengan cara metode sampling jenuh. Menurut Sugiono (2014) sampling jenuh yaitu teknik penentuan sampel bila semua anggota populasi digunakan sebagai sampel. Hal ini sering dilakukan bila populasi relatif kecil, atau sama dengan 30 orang. Dalam hal ini yang menjadi populasi adalah karyawati di Puskesmas Ayah I yang berjumlah 30 orang. Sampel dalam penelitian ini adalah karyawati di Puskesmas Ayah I yang berjumlah 30 orang.

\section{Alat Analis Data}

Teknik analisis data meliputi uji kualitas data (uji validitas \& reliabilitas), uji asumsi klasik (uji multikolinearitas, uji heterokedastisitas, \& uji normalitas), uji hipotesis (uji parsial t dan uji simultan F), koefisien determinasi, menggunakan SPSS 24.00. 


\section{Hasil dan Pembahasan}

\section{Uji Validitas dan Reliabilitas}

Uji validitas digunakan untuk mengukur kualitas data dengan mengukur apa yang seharusnya diukur. Uji validitas digunakan untuk mengukur sah atau validnya suatu kuesioner (Ghozali, 2018). Uji validitas dimaksudkan untuk mengetahui apakah butir-butir pernyataan dalam kuesioner cukup valid sebagai instrumen penelitian dengan ketentuan jika hasil $r$ hitungnya lebih besar dari $r$ tabel dan $a<0,05$ maka dinyatakan valid. Nilai $r$ tabel pada derajat kebebasan $(\mathrm{df})=\mathrm{n}-2$ didapat $\mathrm{df}=30-2=38$, diperoleh nilai $\mathrm{r}$ tabel $=$ 0,3610 .

Analisis terhadap hasil uji validitas pada penelitian ini dengan menggunakan bantuan program komputer SPSS 24.0 for windows, menggunakan pearson correlation. Berikut ini uji validitas untuk kuesioner yang diberikan kepada responden dalam bentuk tabel sebagai berikut:

Tabel 1 Hasil Uji Validitas

\begin{tabular}{lcll}
\hline \multicolumn{1}{c}{ Variabel } & Butir & Sign & Status \\
\hline Work Family Conflict & 8 & Signifikan & Valid \\
Job Stress & 7 & Signifikan & Valid \\
Emotional Exhaustion & 3 & Signifikan & Valid \\
Job Performance & 8 & Signifikan & Valid \\
\hline \multicolumn{2}{c}{ Sumber: Data diolah (2020) } &
\end{tabular}

Hasil Uji validitas seluruh pernyataan yang digunaka dalam variabel work family conflict, job stress, emotional exhaustion dan job performance seluruhnya valid.

Tabel 2. Hasil Uji Reliabilitas

\begin{tabular}{lccc}
\hline \multicolumn{1}{c}{ Item Variabel } & $\begin{array}{c}\text { Nilai Cronbach } \\
\text { Alpha } \\
\text { Minimum }\end{array}$ & $\begin{array}{c}\text { Cronbach } \\
\text { Alpha }\end{array}$ & Keterangan \\
\hline Work Family Conflict & 0,60 & 0,653 & Reliabel \\
Job Stress & 0,60 & 0,715 & Reliabel \\
Emotional Exhaustion & 0,60 & 0,663 & Reliabel \\
Job Performance & 0,60 & 0,736 & Reliabel \\
\hline Sumber: Data diolah (2020) & & &
\end{tabular}

Berdasarkan tabel 2 menunjukan empat instrumen yang digunakan dalam penelitian ini, memiliki niali Cronbach's Alpha > Nilai Cronbach Alpha Minimum $(0,60)$ sehingga dapat disimpulkan bahwa semua instrumen dalam penelitian dinyatakan reliabel.

\section{Uji Multikolineritas}

Tabel 3. Uji Multikolonieritas

\begin{tabular}{llll}
\hline \multirow{2}{*}{ Model } & \multicolumn{3}{c}{$\begin{array}{c}\text { Collinearity } \\
\text { Statisics }\end{array}$} \\
\cline { 2 - 3 } & Tolerance & VIF \\
\hline (Constant) & & \\
Work-Family Conflict (X1) &, 887 & 1,127 \\
Job Stress (X2) &, 969 & 1,031 \\
Emotional Exhaustion (X3) &, 903 & 1,108 \\
Sumber: Data diolah (2020) & &
\end{tabular}

Berdasarkan Tabel coefficients di atas dapat dijelaskanbahwa pada bagian collinerity statistic menunjukan angka VIF dibawah 10 dan tolerance di atas 0,1, karena itu model regresi ini tidak terdapat multikolinieritas, sehingga model regresi pada penelitian ini dapat dipakai. 


\section{Uji Heteroskedastisitas}

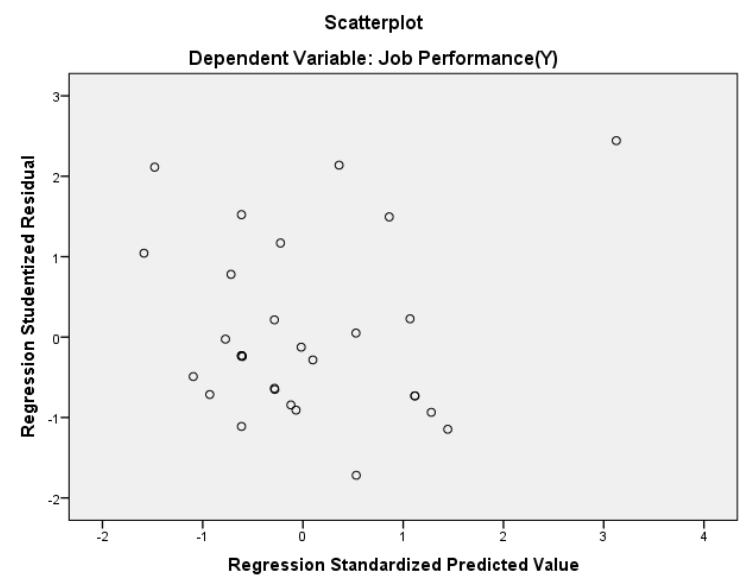

Sumber: Data diolah (2020)

Gambar 2. Uji Heteroskedastisitas

Berdasarkan gambar 2 di atas, menunjukan bahwa bulatan-bulatan kecil tidak memiliki pola tertentu, seperti titik-titik atau bulatan yang membentuk suatu pola tertentu yang teratur (bergelombang, melebar, kemudian menyempit) dan tidak ada pola yang jelas sehingga dapat disimpulkan tidak ada gejala heteroskedastisitas model regresi dalam penelitian ini.

\section{Uji Normalitas}

\section{Gambar 3. Uji Normalitas}

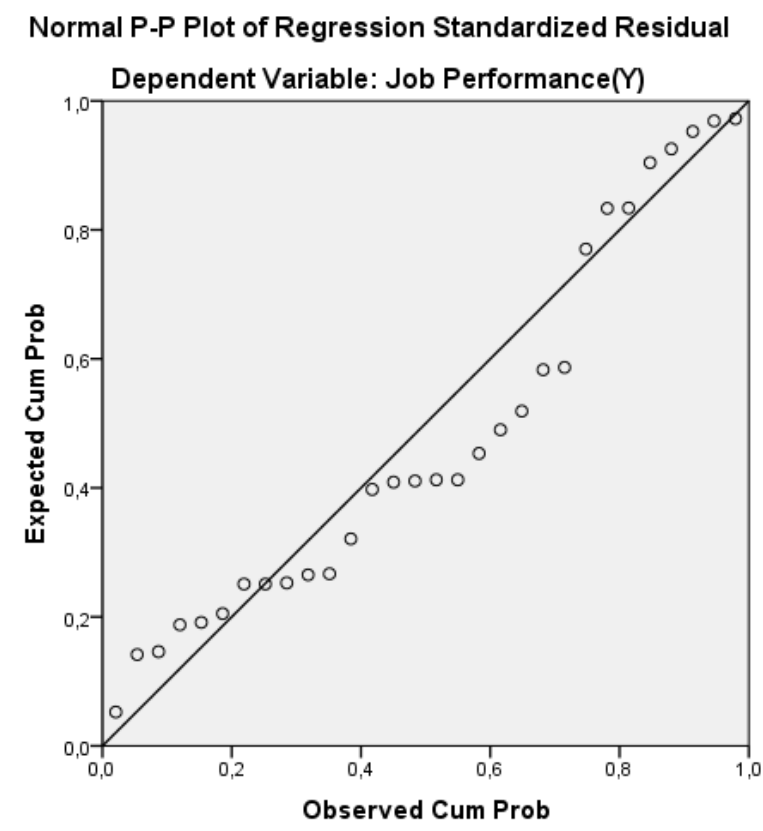

Sumber: Data diolah (2020)

Gambar 3. Uji Normalitas

Berdasarkan gambar 3 uji normalitas di atas terlihat bahwa data menyebar disekitar garis diagonal dan mengikuti arah garis diagonal. Maka model regresi memenuhi asumsi normalitas. 


\section{Analisis Regresi Linier Berganda}

Tabel 4. Ringkasan Hasil Persamaan Regresi Linear Ganda

\begin{tabular}{|c|c|c|c|c|}
\hline & \multirow[t]{2}{*}{ Model } & \multicolumn{2}{|c|}{ Unstandardized Coefficients } & \multirow{2}{*}{$\begin{array}{c}\begin{array}{c}\text { Standardized } \\
\text { Coefficients }\end{array} \\
\text { Beta }\end{array}$} \\
\hline & & B & Std. Error & \\
\hline \multirow{4}{*}{1} & (Constant) & 38,116 & 2,015 & \\
\hline & Work Family Conflict (X1) &,- 241 & 116 & -266 \\
\hline & Job Stress (X2) &,- 477 & 102 &,- 568 \\
\hline & Emotional Exhaustion (X3) &,- 553 & ,226 &,- 309 \\
\hline
\end{tabular}

Dependent Variable: Job Performance (Y)

Sumber: Data diolah (2020)

Berdasarkan perolehan nilai-nilai pada tabel tersebut di atas, maka diperoleh persamaan regresi linear ganda sebagai berikut:

$Y=38,116-0,241 X_{1}-0,477 X_{2}-0,553 X_{3}+e$

1. Nilai konstanta a $=38,116$, berarti apabila variabel work-family conflict (X1), job stress (X2) dan emotional exhaustion (X3) dianggap nol, maka besarnya skor job performance Pada Karyawati di Puskesmas Ayah I yaitu 38,116.

2. Nilai b1 $=-0,241$, berarti apabila terjadi kenaikan skor variabel work-family conflict (X1) sebesar 1 satuan akan menurukan job performance pada karyawati di Puskesmas Ayah I sebesar $-0,241$.

3. Nilai b2 $=0,-477$, berarti apabila terjadi kenaikan skor variabel job stress (X2) sebesar 1 satuan, akan menurukan skor job performance pada karyawati di Puskesmas Ayah I sebesar $-0,477$.

4. Nilai b3 $=-0,553$, berarti apabila terjadi kenaikan skor variabel emotional exhaustion (X3) sebesar 1 satuan, akan menurukan skor job performance pada karyawati di Puskesmas Ayah I sebesar -0,553.

\section{Uji t (Parsial)}

\begin{tabular}{lcccc}
\hline \multicolumn{7}{c}{ Tabel. 5 Uji t } \\
No. $\quad$ Variabel & $\begin{array}{c}\text { Nilai } \\
\text { thitung }\end{array}$ & $\begin{array}{c}\text { Nilai } \\
\text { ttabel }\end{array}$ & Signifikansi & Keterangan \\
\hline 1. Work Family Conflict (X1) & $-2,083$ & $-2,051$ &, 047 & Berpengaruh \\
2. Job Stress (X2) & $-4,660$ & $-2,051$ &, 000 & Berpengaruh \\
3. Emotional Exhaustion (X3) & $-2,448$ & $-2,051$ &, 021 & Berpengaruh \\
\hline
\end{tabular}

Sumber: Data diolah (2020)

Berdasarkan Tabel diatas di atas maka dapat di simpulkan sebagai berikut:

1. Hasil uji t pada tabel IV-14 di atas menunjukan bahwa probabilitas signifikansi untuk variabel Work-family conflict sebesar 0,047 < 0,05 dan hasil perhitungan diperoleh angka $t_{\text {hitung }}-2,083>t_{\text {tabel }}-2,051$. Hasil ini menyatakan bahwa hipotesis H1 diterima yang berarti work-family conflict berpengaruh negatif dan signifikan terhadap job performance pada karyawati Puskesmas Ayah I.

2. Hasil uji t pada Tabel IV-14 di atas menunjukan bahwa probabilitas signifikansi untuk variabel job stress sebesar 0,000 $<0,05$ dan hasil perhitungan diperoleh angka thitung $-4,660>$ $t_{\text {tabel }}-2,051$. Hasil ini menyatakan bahwa hipotesis $\mathrm{H} 2$ diterima yang berarti job stress berpengaruh negatif dan signifikan terhadap job performance pada karyawati Puskesmas Ayah I.

3. Hasil uji t pada tabel IV-14 di atas menunjukan bahwa probabilitas signifikansi untuk variabel emotional exhaustion sebesar 0,021 $<0,05$ dan hasil perhitungan diperoleh angka $t_{\text {hitung }}-2,448>$ $t_{\text {tabel }}-2,051$. Hasil ini H3 diterima yang berarti emotional exhaustion berpengaruh negatif dan signifikan terhadap job performance pada karyawati Puskesmas Ayah I. 


\section{Uji Simultan F}

Tabel 6. Ringkasan Hasil Uji

\begin{tabular}{|c|c|c|c|c|c|c|}
\hline \multicolumn{2}{|c|}{ Model } & Sum of Squares & Df & Mean Square & $\mathrm{F}$ & Sig. \\
\hline \multirow{3}{*}{1} & Regression & 62,645 & 3 & 20,882 & 14,470 &, $000^{\mathrm{b}}$ \\
\hline & Residual & 37,522 & 26 & 1,443 & & \\
\hline & Total & 100,167 & 29 & & & \\
\hline
\end{tabular}

a. Dependent Variable: Job Performance (Y)

b. Predictors: (Constant), Emotional Exhaustion (X3), Job Stress (X2), Work-Family Conflict (X1)

Sumber: Data diolah (2020)

Dari tabel di atas diperoleh $F_{\text {hitung }}$ adalah 14,470 $>F_{\text {tabel }}$ 3,32, dengan tingkat signifikan 0,000. Karena signifikan lebih kecil dari 0,05 sehingga diartikan bahwa variabel work-family conflict, job stress dan emotional exhaustion berpengaruh signifikan secara bersama-sama (simultan) terhadap job performance pada karyawati Puskesmas Ayah I. Hasil ini menunjukan bahwa H4 diterima.

\section{Uji Koefisien Determinasi}

Tabel 7. Uji Koefisien Determinasi

\begin{tabular}{|c|c|c|c|}
\hline Model & $\mathbf{R}$ & Adjusted R Square & $\begin{array}{l}\text { Std. Error of the } \\
\text { Estimate }\end{array}$ \\
\hline 1 &, $791^{a}$ & 625 & 1,20131 \\
\hline
\end{tabular}

Berdasarkan hasil di atas, hasil pengujian menunjukan bahwa nilai Adjusted $R$ Square persamaan diatas sebesar 0,582, artinya 58,2 \% variabel job performance karyawati di Puskesmas Ayah I dapat dijelaskan oleh variabel work-family conflict, job stress, dan emotional exhaustion sedangkan sisanya $41,8 \%$ dapat dijelaskan oleh variabel lain diluar model penelitian ini.

\section{Pembahasan}

\section{Pengaruh Work-Family Conflict Terhadap Job Performance.}

Pengujian hipotesis pertama dilakukan untuk mengetahui pengaruh work-family conflict terhadap job performance. Berdasarkan hasil uji $t$ diperoleh angka $t_{\text {hitung }}-2,083>t_{\text {tabel }}-2,051$, dengan tingkat signifikansi sebesar 0,047 <0,05. Hasil ini menyatakan bahwa semakin tinggi work-family conflict para karyawati di Puskesmas Ayah I maka job performance karyawati di Puskesmas Ayah I juga akan menurun. Hasil penelitian ini sejalan dengan hasil penelitian yang dilakukan oleh Reni Agustina dan I Gede Adnyana Sudibya (2018) yang menyatakan bahwa work family conflict berpengaruh negatif dan signifikan terhadap kinerja, hal ini berarti bahwa semakin tinggi work family conflict yang dialami perawat, maka semakin rendah kinerja yang dihasilkan.

Hasil penelitian ini menunjukkan bahwa karyawati yang sudah berkeluarga mengalami work family conflict dimana karyawati menjalani peran sebagai karyawati dan ibu rumah tangga sekaligus sehingga otomatis beban kerja juga lebih banyak, disatu sisi harus merawat pasien dan juga mengurus suami dan anak. Karyawati susah membagi waktu antara pekerjaan dan urusan rumah tangga, oleh karena itu maka instansi perlu untuk memberikan waktu luang yang lebih dan kebijakan-kebijakan lain yang memang diperlukan oleh karyawati terutama karyawati yang sudah berkeluarga sehingga dapat mengurangi work family conflict yang dialami karyawati di Puskesmas Ayah I. 


\section{Pengaruh Job Stress Terhadap Job Performance.}

Pengujian hipotesis kedua dilakukan untuk mengetahui pengaruh job stress terhadap job performance. Berdasarkan hasil uji $t$ diperoleh angka $t_{\text {hitung }}-4,660>t_{\text {tabel }}-2,051$, dengan tingkat signifikansi sebesar 0,000 $<0,05$. Hasil ini menyatakan bahwa apabila job stress yang dialami karyawati di puskesmas Ayah I meningkat maka job performance karyawati di Puskesmas Ayah I juga akan menurun. Hasil penelitian ini sejalan dengan hasil penelitian yang dilakukan oleh Mokhamad Afif Faudin, et all (2016) yang menyatakan bahwa stres kerja berpengaruh negatif dan signifikan terhadap kinerja, hasil ini menunjukan bahwa semakin tinggi stres kerja maka semakin rendah kinerja perawat Instalasi Rawat Inap Rumah Sakit Militer Kota Malang.

Hasil penelitian ini menyatakan bahwa job stress berpengaruh negatif dan signifikan terhadap job performance, yang artinya tinggi rendahnya job stress berpengaruh terhadap job performance karyawati, pada kategori stres rendah sampai sedang dapat mendorong dan meningkatkan kinerja karyawati akan tetapi pada kategori stres tinggi cenderung menurunkan kinerja karyawati tersebut, oleh karena itu instansi perlu memperhatikan job stress yang di alami karyawati di Puskesmas Ayah I, diantaranya dengan cara motivasi, sosialisasi dan lain sebagainya, ini bertujuan untuk meningkatkan job performance dari karyawati di puskesmas Ayah I.

\section{Pengaruh Emotional Exhaustion Terhadap Job Performance.}

Pengujian hipotesis ketiga dilakukan untuk mengetahui pengaruh emotional exhaustion terhadap job performance. Berdasarkan hasil uji $t$ diperoleh angka $t_{\text {hitung }}-2,448>t_{\text {tabel }}-2,051$, dengan tingkat signifikansi sebesar 0,021 <0,05. Hasil ini menyatakan bahwa semakin meningkat emotional exhaustion yang dialami karyawati di puskesmas Ayah I maka job performance karyawati di Puskesmas Ayah I juga akan menurun.

Hasil penelitian ini sejalan dengan hasil penelitian yang dilakukan oleh Dewi Ayu Lestari dan Budiono (2021) yang menyatakan emotional exhaustion mempunyai pengaruh yang negatif dan signifikan terhadap job performance perawat wanita di Rumah Sakit Petrokimia Gresik. Hasil penelitian ini menunjukan bahwa instansi perlu meminimalisir emotional exhaustion yang di alami karyawati di Puskesmas Ayah I, contohnya dengan cara senam pagi dan sarapan bersama, mengadakan family gathering tiap satu tahun sekali.

\section{Pengaruh Work-Family Conflict, Job Stress, Dan Emotional Exhaustion Secara Simultan Terhadap Job Performance.}

Pengujian hipotesis keempat dilakukan untuk mengetahui pengaruh work-family conflict, job stress, dan emotional exhaustion secara simultan terhadap job performance. Berdasarkan hasil uji $\mathrm{F}$ diperoleh diperoleh $F_{\text {hitung }}$ adalah 14,470 $>F_{\text {tabel }} 3,32$, dengan tingkat signifikan 0,000. Karena signifikan lebih kecil dari 0,05 sehingga diartikan bahwa variabel work-family conflict, job stress, dan emotional exhaustion berpengaruh signifikan secara bersama-sama (simultan) terhadap job performance karyawati di Puskesmas Ayah I. Hasil ini menunjukkan jika job performance karyawati di Puskesmas Ayah I di pengaruhi oleh work-family conflict, job stress, dan emotional exhaustion.

\section{Hasil Uji Koefisien Determinasi}

Hasil pengujian menunjukan bahwa nilai Adjusted $R$ Square persamaan diatas sebesar 0,582, artinya 58,2 \% variabel job performance karyawati di Puskesmas Ayah I dapat dijelaskan oleh variabel work-family conflict, job stress, dan emotional exhaustion sedangkan sisanya $41,8 \%$ dapat dijelaskan oleh variabel lain diluar model penelitian ini. Job 
performance karyawati di Puskesmas Ayah I ditentukan oleh banyak faktor, tiga faktor diantaranya adalah work-family conflict, job stress, dan emotional exhaustion oleh karena itu salah satu langkah yang dapat diupayakan manajemen untuk meningkatkan job performance karyawati di Puskesmas Ayah I yaitu melalui perbaikan work-family conflict, job stress, dan emotional exhaustion yang ada di alami oleh para karyawati.

\section{Penutup dan Saran}

\section{Simpulan}

Berdasarkan penelitian di atas tentang work-family conflict, job stress, dan emotional exhaustion terhadap job performance karyawati di Puskesmas Ayah I dengan responden sebanyak 30 orang responden maka dapat diambil kesimpulan adalah sebagai berikut: 1.) Hasil penelitian ini menyatakan bahwa work-family conflict berpengaruh negatif dan signifikan terhadap job performance karyawati di Puskesmas Ayah I; 2.) Hasil penelitian ini menyatakan bahwa job stress berpengaruh negatif dan signifikan terhadap job performance karyawati di Puskesmas Ayah I; 3.) Hasil penelitian ini menyatakan bahwa emotional exhaustion berpengaruh negatif dan signifikan terhadap job performance karyawati di Puskesmas Ayah I; 4.) Hasil penelitian ini menyatakan bahwa work-family conflict, job stress, dan emotional exhaustion secara simultan berpengaruh secara bersama-sama (simultan) terhadap job performance karyawati di Puskesmas Ayah I, uji koefisien determinasi menunjukan bahwa 58,2\% variabel job performance karyawati di Puskesmas Ayah I dapat dijelaskan oleh variabel work-family conflict, job stress, dan emotional exhaustion.

\section{Saran}

Adapun saran dalam penelitian ini adalah sebagai berikut: 1.) Work-family conflict berpengaruh negatif dan signifikan terhadap job performance. Hasil penelitian menunjukan bahwa instansi perlu untuk memberikan waktu luang yang lebih dan kebijakan-kebijakan lain yang memang diperlukan oleh karyawati terutama karyawati yang sudah berkeluarga sehingga dapat mengurangi work family conflict yang dialami karyawati di Puskesmas Ayah I; 2.) Job stress berpengaruh negatif dan signifikan terhadap job performance. Hasil penelitian menunjukan bahwa pihak instansi perlu memperhatikan job stress yang di alami karyawati di Puskesmas Ayah I, diantaranya dengan cara motivasi, sosialisasi dan lain sebagainya, ini bertujuan untuk meningkatkan job performance dari karyawati di puskesmas Ayah I; 4.) Emotional exhaustion berpengaruh negatif dan signifikan terhadap job performance. Hasil penelitian menunjukan bahwa pihak instansi perlu meminimalisir emotional exhaustion yang di alami karyawati di Puskesmas Ayah I, contohnya dengan cara senam pagi dan sarapan bersama, mengadakan family gathering tiap satu tahun sekali; 5.) Penelitian selanjutnya diharapkan mampu melengkapi keterbatasan penelitian, mengingat penelitian ini hanya membatasi pada variabel work-family conflict, job stress dan emotional exhaustion terhadap job performance sedangkan masih banyak variabel lain yang dapat mempengaruhi job performance misalnya karakteristik individu, beban kerja, dan lain sebagainya; 6.) Penelitian yang selanjutnya diharapkan mampu memaksimalkan responden yakni bukan hanya karyawati ASN melainkan juga yang berstatus non ASN. 


\section{Referensi}

Agustina, R., \& Sudibya, I. G. A. (2018). Pengaruh Work Family Conflict Terhadap Stres Kerja dan Kinerja Wanita Perawat Di Rumah Sakit Umum Daerah Praya Lombok. EJurnal Ekonomi Dan Bisnis Universitas Udayana, 7(3), 775-808.

Ardiansah, N., Anis K, M., \& Sutapa, S. (2003). Pengaruh Kepuasan Kerja dan Komitmen Organisasional terhadap Keinginan Berpindah Kerja Auditor (Studi Kasus pada KAP di Jawa Tengah ). EKOBIS, 4(2), 141-152.

Aronson, E. (1989). Career burnout: Causes and cures. New York: Free Press; London: Collier Macmillan.

Faudin, M. A., \& Sungkawati, E., \& Samiadji, S. (2016). Pengaruh Stres Kerja Terhadap Kinerja Perawat Melalui Kepuasan Kerja (Studi pada Perawat Instalasi Rawat Inap Rumah Sakit Militer Kota Malang). Manajemen \& Bisnis Jurnal, 2(2).

Frone, M. R. (2000). Work-family conflict and employee psychiatric disorders: The national comorbidity survey. Journal of Applied psychology, 85(6), 888-895.

Gaines, J., \& Jermier, J. M. (1983). Emotional exhaustion in a high stress organization. Academy of Management journal, 26(4), 567-586.

Ghozali, I. (2009). Aplikasi Analisis Multivariate dengan Program SPSS. Semarang: Penerbit Universitas Diponegoro.

Gomes, F. C. (2000). Manajemen Sumber Daya Manusia, Cetakan. Keempat. Yogyakarta: Penerbit Andi.

Greenhaus, J. H., \& Beutell, N. J. (1985). Sources of conflict between work and family roles. Academy of management review, 10(1), 76-88.

Hasibuan, M. S. P. (2014). Manajemen Sumber Daya Manusia, edisi revisi, cetakan kedelapan belas. Penerbit: Bumi Aksara, Jakarta.

Khoiriyah, N. (2011). Faktor-Faktor Yang Berhubungan dengan Motifasi Lansia Berkunjung Ke Posyandu Lansia Di RW II Kelurahan Margorejo Kecamatan Cepiring Kabupaten Kendal. Skripsi. Universitas Muhammadiyah Semarang.

Lestari, D. A., \& Budiono, B. (2020). Pengaruh Work Family Conflict dan Emotional Exhaution terhadap Kinerja Perawat Wanita melalui Organizational Commitment pada Rumah Sakit Petrokimia Gresik. Jurnal Ilmu Manajemen, 9(1).

Luthans, F. (2011). Perilaku Organisasi. Yogyakarta: Andi

Mangkunegara, A. A. P. (2010). Manajemen Sumber Daya Manusia Perusahaan. Bandung: PT Remaja Rosdakarya

Maslach, C., Schaufeli, W. B., \& Leiter, M. P. (2001). Job Burnout. Annual Review of Psychology, 52(1), 397-422.

Miranda, D. (2013). Strategi Coping Dan Kelelahan Emosional (Emotional Exhaustion) Pada Ibu Yang Memiliki Anak Berkebutuhan Khusus. Psikoborneo: Jurnal Ilmiah Psikologi, 1(2), 133-145. 
Jurnal Ilmiah Mahasiswa Manajemen, Bisnis dan Akuntansi 3(2) April 2021

Posig, M., \& Kickul, J. (2004). Work-role expectations and work family conflict: gender differences in emotional exhaustion. Women in Management Review.

Sugiyono. (2014). Metode Penelitian Bisnis. Bandung: Alfabeta. 